\title{
An advancing glacier in a recessive ice regime: Berlingske Bræ, North-West Greenland
}

\author{
Peter R. Dawes and Dirk van As
}

Greenland is receiving unprecedented international attention, both in scientific and political circles. Characterised by a central ice sheet up to $3.4 \mathrm{~km}$ thick (Inland Ice), numerous ice caps and hundreds of outlet glaciers debouching into the surrounding oceans, Greenland supports the second largest ice mass in the world. Analysis of glacier movements, melt rates and ice loss to the sea, provide data with which to assess mass balance changes and thereby predict global sealevel rise. Thus Greenland plays a central role in the current worldwide debate on climate change.

Present-day dynamic ice loss is invariably advertised by the fast moving glaciers of western Greenland with their spectacular calf ice production, such as the ice streams around Disko Bugt reviewed by Weidick \& Bennike (2007). This tends to overshadow ice stability and expansion seen in the form of stationary and advancing glaciers elsewhere in Greenland (MODIS 2009). While the seawards acceleration of glacier flow and retreat in frontal positions can be readily attributed to a shift in atmospheric and oceanic conditions (global warming), the same explanation can hardly be used for glaciers with contrasting movement histories.

\section{Aim of this paper}

We focus on three west coast, marine-terminating glaciers between $75^{\circ}$ and $78^{\circ} \mathrm{N}$ (Fig. 1) to elucidate the retreat-advance paradox referred to above. Steenstrup Gletscher and Tracy Gletscher are chosen to illustrate the regional pattern of ice recession, including massive ice wasting on a broad front in Melville Bugt, whereas Berlingske Bræ defies this trend by long-lasting advance. The receding glaciers Steenstrup and Tracy are known from regional surveys (e.g. Kollmeyer 1980; Rignot \& Kanagaratnam 2006), but the advancing glacier Berlingske Bræ has only been cursorily mentioned in map descriptions (Dawes 1992, 2006).

We present maps showing the terminus fluctuations of the three glaciers based on historical records (Figs 2-4) but the paper's four-page limit prohibits discussion of the early sources. This aspect, climatic records and their relation to ice fluctuations, and comparisons with other Greenland glaciers, will be dealt with in a forthcoming paper.

\section{Historical sources and the $\mathbf{2 0 0 9}$ database}

T.C. Chamberlin and R.D. Salisbury were the first to investigate glaciers in the region in 1894-95 when they reached as far north as Inglefield Bredning, the location of our northern glacier (Tracy Gletscher). The next milestone was the regional mapping by geologist and cartographer Lauge Koch between 1916 and 1923 who surveyed and described glaciers throughout the region. The 1940s heralded a new era of research with the incoming of aerial photographs and such images are available from the period 1948-1985. Finally in the last decades, satellite images have assured a continual record of the areas covered and uncovered by Greenland glaciers (Weidick 1994). In this paper we make use of such imagery from the period 1963-2009. Table 1 summarises our data sources.

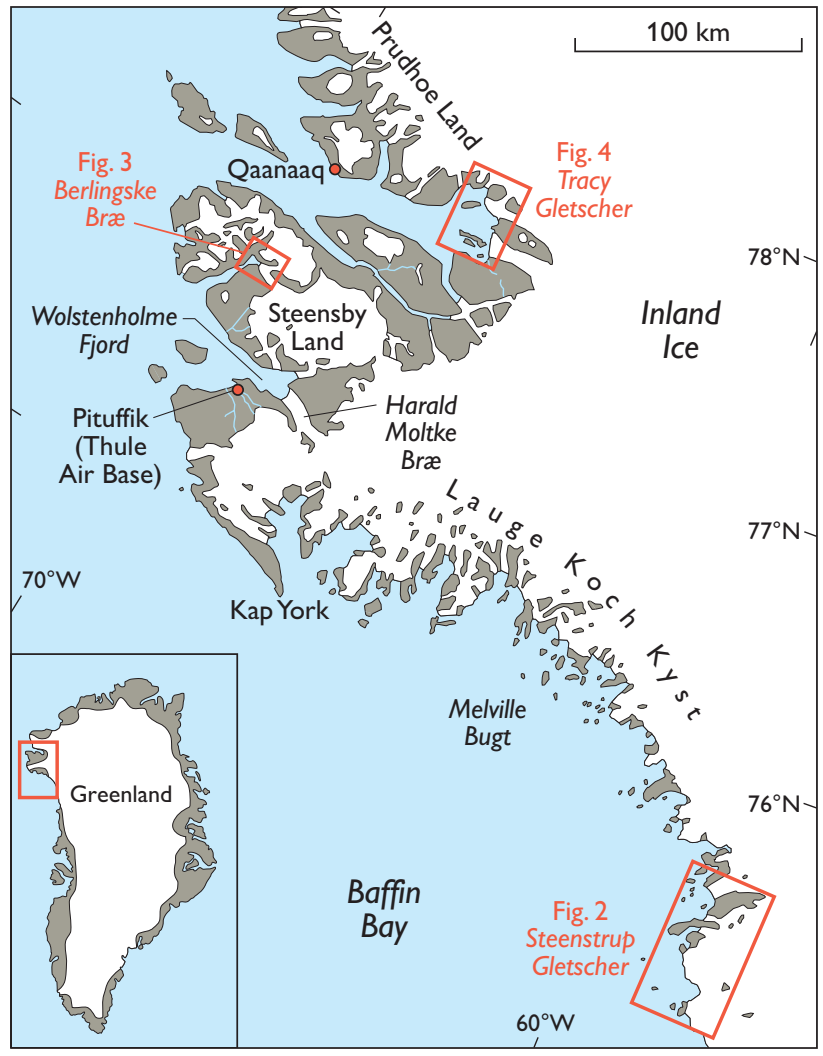

Fig. 1. Map of North-West Greenland showing the locations of the three studied glaciers featured in Figs 2-4. 


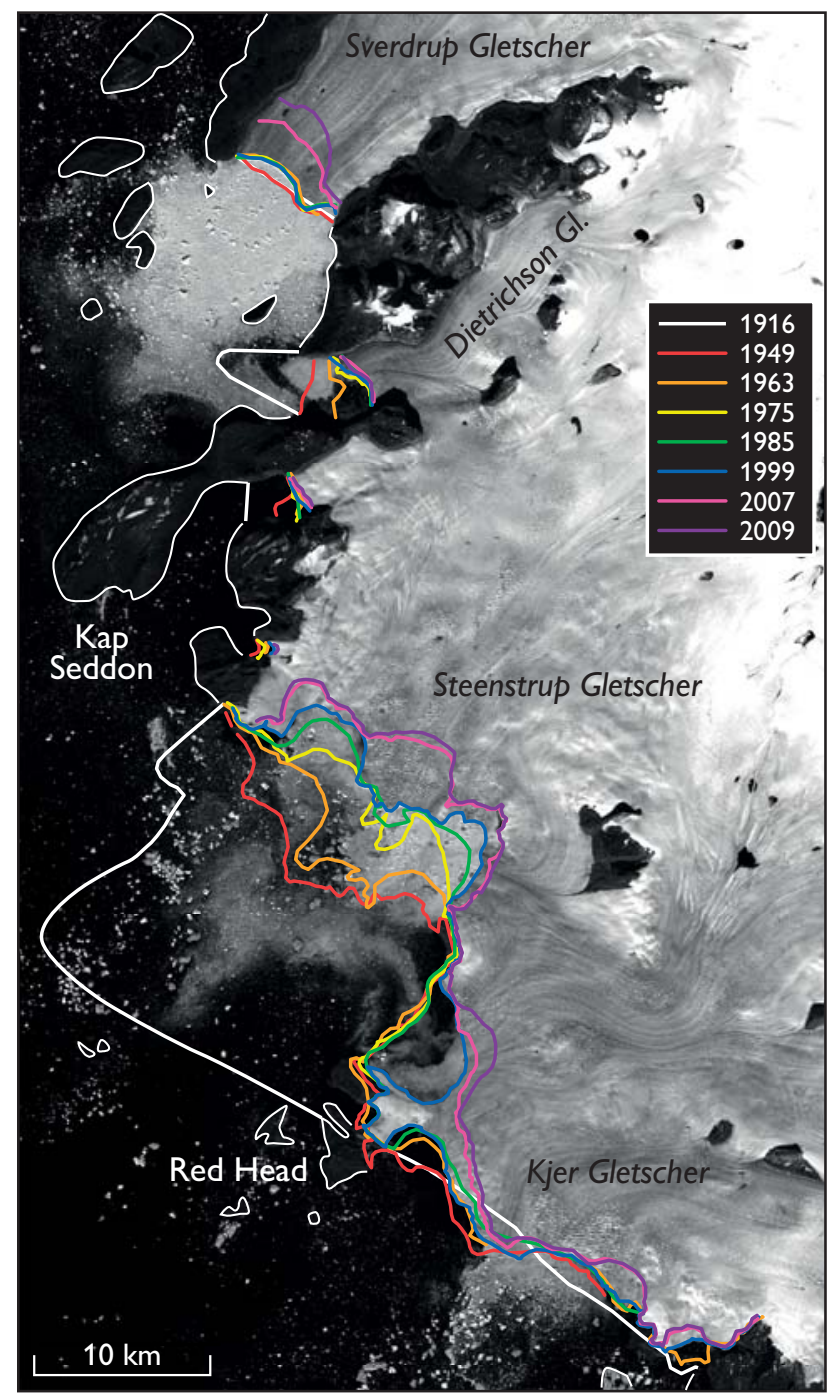

Fig. 2. Satellite image of Steenstrup Gletscher and neighbouring glaciers, southern Melville Bugt, showing eight frontal positions from 1916 to 2009. Thin, white line: coastline. For sources, see Table 1.

\section{Steenstrup Gletscher, Melville Bugt}

Steenstrup Gletscher is the widest glacier of the impressive ice front that characterises Lauge Koch Kyst and that calves into Melville Bugt (Figs 1, 2). Stretching from the Kap Seddon peninsula to Red Head, where Steenstrup Gletscher borders the fairly stable Kjer Gletscher, the glacier has an irregular and crevassed floating tongue more than $30 \mathrm{~km}$ wide. Ice production from the central part is spectacular, both as regards the number of calved bergs and their size. Koch (1928) noted that large portions of the $25 \mathrm{~m}$ high floating tongue become detached and move seawards before being broken up, while Kollmeyer (1980) described the calving of 'jigsaw puzzle type' icebergs in excess of $1 \mathrm{~km}$ in length.

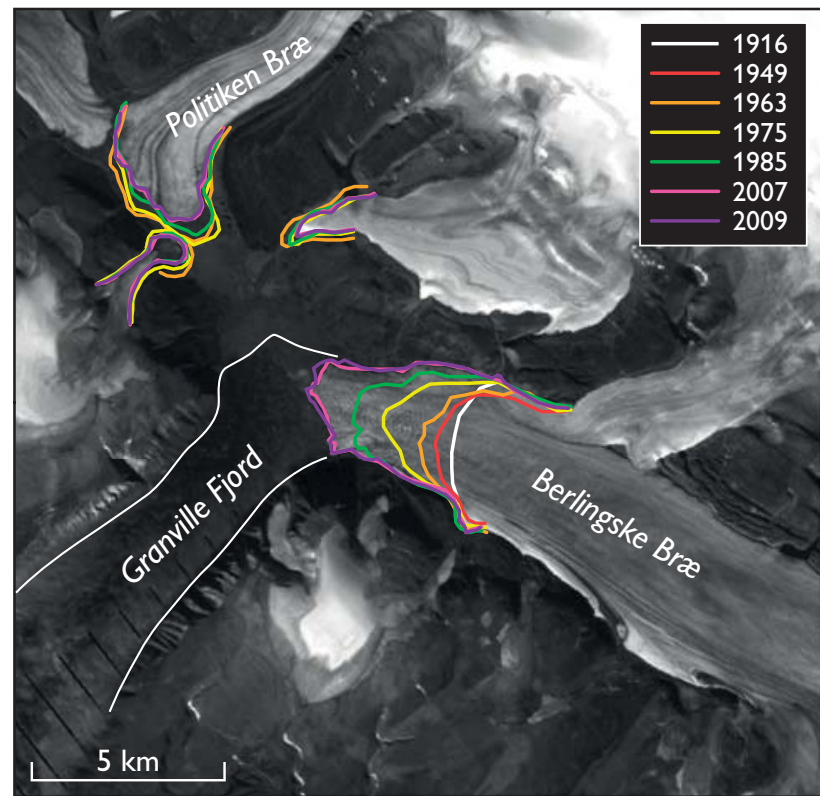

Fig. 3. Satellite image of Berlingske Bræ, Granville Fjord showing seven frontal positions from 1922 to 2009. Thin, white line: coastline. For sources, see Table 1.

As illustrated by Fig. 2, the main fluctuations affected the central part of the floating tongue where drawback since 1916 is almost $25 \mathrm{~km}$. Melville Bugt is noted for its ice-infested waters during summer months and the records show that the nature and position of the ice front can change seasonally depending on the degree of ice congestion. In five months, from spring to autumn 1916, the central part of the front had moved westwards by $c .1 \mathrm{~km}$ while in 1920 , after a summer when Melville Bugt was free of ice, there was recession of more than $6 \mathrm{~km}$ (Koch 1928). In contrast, the northern segment of the terminus was stationary between 1916 and 1923 .

Table 1. Data for North-West Greenland glacier fluctuations

\begin{tabular}{lll}
\hline Year & Type/Medium & Source \\
\hline 1892 & Field/Map & Peary (1892) \\
1916 & Field/Map & Koch (1922) \\
1922 & Field/Map & Koch (1932) \\
$1949^{*}$ & OAP $/$ Map & Geodetic Institute \\
1953 & VAP $\ddagger$ & U.S. military \\
1963 & Satellite & Zhou \& Jezek (2003) \\
1971 & VAP & Greenarctic Consortium \\
1985 & VAP & Geodetic Institute \\
1975 & & \\
1999 & & NASA and U.S. \\
2007 & Landsat & Geological Survey \\
2009 & satellite & \\
\hline
\end{tabular}

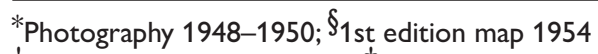

tOblique aerial photography; ${ }^{\ddagger}$ Vertical aerial photography 
The shrinkage shown in Fig. 2 has produced new bedrock exposures, and Red Head, which was a semi-nunatak in 1916 , became an island in 2005.

\section{Berlingske Bræ, Granville Fjord}

Berlingske Bræ flows westwards into the head of Granville Fjord from the major ice cap of Steensby Land that has a bridge connection with the Inland Ice (Figs 1, 3). It is the only glacier of several draining into Granville Fjord that currently reaches the sea. The glacier has a rather low gradient and its flow pattern can be traced for about $25 \mathrm{~km}$ before being lost to the ice cap. The glacier trunk is $3-4 \mathrm{~km}$ wide, and today the terminus is irregular, rather slender and crevassed, and over $2 \mathrm{~km}$ across. It is unknown whether the snout is afloat, but the apparent lack of iceberg production suggests it is grounded. An unnamed tributary originating from a more westerly ice cap joins the northern flank of Berlingske Bræ contributing to its westerly flow into Granville Fjord.

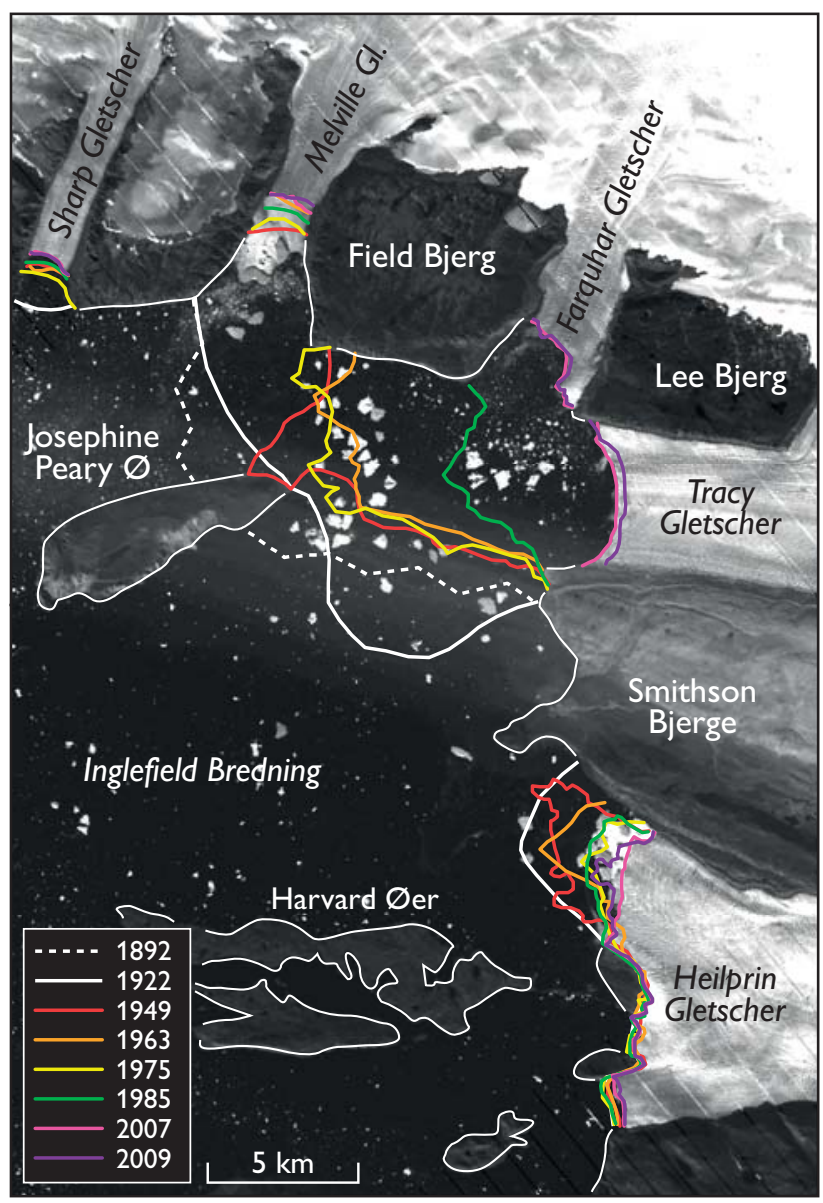

Fig. 4. Satellite image of Tracy Gletscher and neighbouring glaciers, Inglefield Bredning, showing eight frontal positions from 1892 to 2009. Thin, white line: coastline. For sources, see Table 1.
The terminus positions shown in Fig. 3 illustrate a continuous ice advance in excess of $4 \mathrm{~km}$ in the last 85 years that has changed the glacier front from being terrestrial to marine. As opposed to when the glacier terminated on land, its tongue now is strongly tapering. The glacier has overrun the entire alluvial gravel plain that in the early 20 th century extended beyond its snout and separated it from the fjord, and it has also engulfed bedrock exposures on its southern flank that were mapped by the first author in 1974 .

\section{Tracy Gletscher, Inglefield Bredning}

Tracy Gletscher is the second largest of six outlet glaciers that debouch into the headwaters of Inglefield Bredning (Figs 1, 4). It is about $5 \mathrm{~km}$ wide with a steep front that has a regular concave trace which is probably afloat. The flow pattern of the glacier is recognisable over $30 \mathrm{~km}$ before being lost to the east to the Inland Ice proper.

The 115-year record (Fig. 4) shows substantial ice wasting amounting to frontal recession of $c .15 \mathrm{~km}$. The terminus positions show that for a century (1892-1985) Tracy Gletscher was coalesced with Farquhar Gletscher. In 1923 the seaward front of the floating confluent ice embracing Melville Gletscher was a cliff $20 \mathrm{~m}$ high and $19 \mathrm{~km}$ long (Koch 1928). Over the past century the glacier tongue has lost about 100 $\mathrm{km}^{2}$ of ice, which represents at least $20 \mathrm{~km}^{3}$ based on Koch's observation.

Recession with the impressive break-up of the confluent ice mass has led to striking landscape changes. For example, longtime nunataks Lee Bjerg and Field Bjerg are now lapped by the sea, while Josephine Peary $\varnothing$ finally lives up to its name as an island being eventually released from the ice around 1960 (Inûterssuaq Uvdloriaq, personal communication 1971).

\section{Recent glacial history: retreat versus advance}

The glaciers of North-West Greenland and their marginal deposits are shown on the Thule 1:500 000 scale geological sheet, and a summary of glacial history is given in the map description (Dawes 2006). The regional pattern of spatial change seen in terms of terminal positions between 1948-50 and 1985 is shown on the maps of Dawes (1988). This information, plus the early records summarised by Koch (1928), the regional analysis of Davies \& Krinsley (1962) and satellite data of the last decades, demonstrate that the general recession of the Inland Ice and its outlet glaciers is regional in character and persistent for more than a century. The drastic deglaciation of Melville Bugt has brought the ice limit there close to the early Holocene position (Bennike 2008). 
The overall pattern is that glaciers with floating tongues, like Steenstrup and Tracy, have shown by far the largest retreat and ice wastage. The most extensive ice withdrawal has been along the heavily glaciated Lauge Koch Kyst, where the lowering ice surface is being pierced by its rock substratum and where nunataks have become shoreline, and ice-rooted peninsulas insular. However, some glaciers show current fast retreat after decades of stability (e.g. Sverdrup Gletscher; Fig. 2). In general, land-based glaciers show relatively sluggish movement, and some have been almost stationary or only show minor retreat (e.g. Prudhoe Land glaciers; Dawes 2006). It is clear that given the existence of a detailed database, the general recession can be seen to have been interrupted by short periods of comparative stability and even advance (e.g. Harald Moltke Bræ; Mock 1966).

In contrast to this regional recessive regime, Berlingske Bræ shows continual advance for at least 85 years. An explanation of this deviant behaviour must be sought in the fact that the glacier originates from an independent ice cap that responds to changes in temperature and precipitation differently than the Inland Ice. The glacier advance can be a response to increased precipitation on the ice cap or increased basal sliding, both of which could be related to the observed increase in atmospheric temperatures. No matter which, the advance of Berlingske Bræ over such a long period is unexpected in a warming climate.

\section{Conclusions, relevance to global climate research and future work}

Berlingske Bræ is located between Steenstrup Gletscher and Tracy Gletscher that are $340 \mathrm{~km}$ apart. The two receding glaciers compare with others in Melville Bugt (and in other areas of Greenland) indicating changed mass balance of their source: the Inland Ice. The main causes of this long-lasting change - documented in our data back to 1892 - must be regional, and thus the present warming climate must affect the process. However, whatever the fundamental cause (or causes) controlling regional meltdown, it has been a subordinate factor at Berlingske Bræ where there is long-standing advance.

Seen in terms of the regional, recessive ice regime in which it is located, Berlingske Bræ is anomalous and thus outside mainstream research concerning analysis of dwindling ice masses and their response to global warming. However, if we are to understand the underlying complex processes, and ultimately the effect of climate change on the regional recessive regime, attention should also be paid to such glaciers. Among other things, this research should be directed to discovering why receding and expanding glaciers with century-long contrasting histories occur side by side.

This paper is a contribution to international promotion of this aspect of glacioclimatic research in progress at the Survey, both in our study region and elsewhere in Greenland (e.g. Weidick 2009).

\section{References}

Bennike, O. 2008: An early Holocene Greenland whale from Melville Bugt, Greenland. Quaternary Research 69, 72-76.

Davies, W.E. \& Krinsley, D.B. 1962: The recent regimen of the ice cap margin in North Greenland. International Association of Scientific Hydrology 58, 119-130.

Dawes, P.R. 1988: Geological map of the Thule district, North-West Greenland. 1:100 000 sheets 1-6 and 1:200 000 sheets 7-11. Unpublished maps, Geological Survey of Denmark and Greenland, Copenhagen.

Dawes, P.R. 1992: New geological map of the Thule region, North-West Greenland. Rapport Grønlands Geologiske Undersøgelse 155, 42-47.

Dawes, P.R. 2006: Explanatory notes to the Geological map of Greenland, 1:500 000, Thule, Sheet 5. Geological Survey of Denmark and Greenland Map Series 2, 97 pp.

Koch, L. 1922: Note to maps of Melville Bay from Wilcox Point to Cape York and of North Greenland from $81^{\circ}-83^{\circ} 35^{\prime} \mathrm{N}, 38^{\circ}-56^{\circ} \mathrm{W}$. Meddelelser om Grønland 64(2), 77-88.

Koch, L. 1928: Contributions to the glaciology of North Greenland. Meddelelser om Grønland 65(2), 183-464.

Koch, L. 1932: Map of North Greenland, scale 1:300,000. Copenhagen: Geodetic Institute, 19 sheets.

Kollmeyer, R.C. 1980: West Greenland outlet glaciers: an inventory of the major iceberg producers. Cold Regions Science and Technology $\mathbf{1}$, 175-181.

Mock, S.J. 1966: Fluctuations of the terminus of the Harald Moltke Bræ, Greenland. Journal of Glaciology 6(45), 369-373.

MODIS 2009: MODIS studies of Greenland. Moderate Resolution Imagery Spectroradiometer, NASA and Byrd Polar Research Center, http//bprc.osu.edu/MODIS/?p=61.

Peary, R.E. 1892: The North Greenland Expedition of 1891-92. Journal of American Geographical Society 24, 536-558.

Rignot, E. \& Kanagaratnam, P. 2006: Changes in the velocity structure of the Greenland ice sheet. Science 311, 986-990.

Weidick, A. 1994: Satellite image atlas of glaciers of the world. Greenland. United States Geological Survey Professional Paper 1386-C, 141 pp.

Weidick, A. 2009: Johan Dahl Land, south Greenland: the end of a 20th century glacier expansion. Polar Record 45(235), 337-350.

Weidick, A. \& Bennike, O. 2007: Glaciation history and glaciology of Jakobshavn Isbræ and the Disko Bugt region, West Greenland: a review. Geological Survey of Denmark and Greenland Bulletin 14,78 pp.

Zhou, G. \& Jezek, K. 2003: DISP yearly satellite photographic mosaics of Greenland 1962-1963. National Snow and Ice Data Center, Boulder, Colorado. Digital media. 